\title{
Article \\ Online Political Campaigning during the 2014 Regional Elections in Poland
}

\author{
Paweł Baranowski \\ Institute of Political Science, University of Wrocław, 51-149 Wrocław, Poland; E-Mail: pawel.baranowski@uni.wroc.pl
}

Submitted: 6 June 2015 | In Revised Form: 18 August 2015 | Accepted: 24 September 2015 |

Published: 29 December 2015

\begin{abstract}
This article is dedicated to the analysis and evaluation of political communication on a regional level. Without any doubt, the Internet revolution affected electoral campaigning on every level. Online campaigning before local elections is often marginalized by political scientists and other scholars researching political marketing. However, the question emerges: are the candidates aware of the possibilities that new media has brought to political communication? Content analysis of all the major online communication tools has allowed the author to analyze the patterns of using websites, official Facebook profiles and Twitter accounts of candidates during the 2014 Lower Silesian Regional assembly elections. The Lower Silesian Voivodeship is among the fastest developing regions in Poland with high Internet penetration rate. Is the Internet campaign treated as a second-class way to communicate with potential voters, or is it perceived as an opportunity to reach electorate online?
\end{abstract}

\section{Keywords}

e-campaigning; Internet; new media; own media; Poland; political communication; regional elections; social media

\section{Issue}

This article is part of the special issue "Turbulences of the Central and Eastern European Media", edited by Epp Lauk (University of Jyväskylä, Finland).

(C) 2015 by the author; licensee Cogitatio (Lisbon, Portugal). This article is licensed under a Creative Commons Attribution 4.0 International License (CC BY).

\section{Introduction}

Many political and communication scientists are stressing the role and importance of communication in the politics (Canel, 1999, p. 15; Dobek-Ostrowska, 2007, chapter 4; Gerstle, 1992, p. 13). The period of political campaign before elections is when the communication with the potential voters becomes crucial for incumbents and challengers, who are willing to obtain the mandate.

The classical "golden triangle" of political communication by Richard Perloff (1998, p. 9) assumes, that the discussion within politics is conducted by the leaders, the media and the public. New media and online communication shortens the distance between the leaders and the public, by allowing the establishment of direct, computer-mediated interaction (Harvey, 2014, p. 36). The classical division of political campaigning by P. Norris (1997, pp. 197-198) is taking into account the evolu- tion of communication technology. Thus, we can speak about pre-modern campaigning in the age of the press, modern campaigning in the age of television and postmodern campaigning, which can be observed right now, in the era of new media.

The importance of new technologies in political marketing has been stressed by many Polish scholars. As Garlicki (2010) mentioned, we can observe a significant role of the Internet in the transition from electoral campaigning to permanent campaign. Internet and new media have been present in Polish election campaigns since the nineties. For the first time, it has been used in 1997, during presidential campaign (Plit, 2008, p. 56), although due to low Internet penetration rate in Poland, it was rather a marginal phenomenon. Further electoral campaigns began to develop the use of new media, and gave the very start of post-modernization stage of political campaigning in Poland. However, the 2011 parliamentary elections was the first time, when 
Internet was used by a broad spectrum of candidates. Scholars from Poland started to analyze election campaigns online, often criticizing politicians for poor design of websites, which appeared like old, web 1.0 bulletin boards. The revolution of social media and web 2.0 forced candidates to implement interaction and interactivity as a vital element of an election campaign. In relation to the stage of campaigning evolution, Poland has been described by scholars as early postmodern. There are several empirical studies, which are supporting that thesis (Baranowski \& Jacuński, 2015; Borek \& Jacuński, 2014), however none of the mentioned research has been done based on candidates in regional elections.

A few months after the European Parliament campaign which took place in May 2014, another election was conducted in Poland. The local elections are allowing citizens to choose their deputies to regional assemblies, such as: Voivodeship Sejmik (regional assembly), municipal council and the mayor of the town, city or rural commune. The Lower Silesia Voivodeship Sejmik (Lower Silesia Regional Assembly) is the assembly on provincial level, which has got the constitutional power of adapting the local law on the matters which are not reserved for the central government. It may seem, that the Voivodeship election campaign could be treated as a second-class and less important both for citizens and political actors. However, they could be treated as a warm-up before presidential and parliamentary campaign. The result of regional elections in 2010 (conducted on $21^{\text {st }}$ of November) wasn't the exact reflection of further ( $9^{\text {th }}$ October) 2011 parliamentary elections, but the ruling party, Civic Platform maintained its first position. Of course, there are a variety of smaller parties and local electoral committees, which are trying to obtain mandates during regional elections.

Polish scholars researching local elections, presented thesis of spatial identity (Bukowski, Flis, Hess, \& Szymańska, 2011, pp. 10). According to the authors, the similar conditions of living within the local society allowed for the construction of strong bonds among its participants which may remain even if the conditions of existence would change. Therefore, in addition to the statement, that parliamentary and presidency elections are more important, the regional elections should be treated by local communities as in popular proverb: "The shirt is nearer to the body than the coat". As for the importance for political actors, apart from the natural tendency of parties to mark their presence in every election, it's enough to mention, that the budget expenditure for Voivodeship Sejmik of Lower Silesia is estimated at 1,4 billion Polish Zloty ("Budżet województwa dolnośląskiego", 2015). Katarzyna Kobielska, scholar researching local governance in Lower Silesia claimed that the game (election campaign to the Voivodeship Sejmiks - PB) is worth the candle (Alberski,
Cichosz, \& Kobielska, 2013, p. 33). The author concludes that apart from the access to a substantial amount of money, the Regional Assemblies is connected with power and influence, and it is often the first step to the national politics. Not as prestigious as European Parliament elections, but also very important for democracy and political system, local elections had a much smaller budget for the electoral campaign. Especially, as the previous elections had cost political parties a significant amount of money. However, the costs of constructing the website and renting the hosting servers are constantly decreasing. The presence in the social media doesn't consume any financial resources and can be very effective tool of interactive, electoral communication. Have the candidates for the local authorities adopted technological innovations?

\section{Research Framework}

\subsection{Methodology}

The empirical method chosen by the author to evaluate the political campaign to Lower Silesia Assembly online is the content analysis. This method allows the researcher to investigate the subject from both a quantitative and a qualitative perspective.

The first step was to construct an original codebook dedicated to regional elections. Codebook consists of three, separate categories. Each category covered a different medium owned by candidates. Categorization key dedicated to the websites consisted of 28 questions, and analyzed the technological features of the page, sharing potential, owners' activity and possibilities of interaction with the candidate. The multimedia potential, newsletter possibility and static information was also taken into account. These issues could indicate the assignment of a webpage to web 1.0 era. Second categorization key with 20 questions investigated Facebook activity: standard popularity indicators, shared content and the intensity of posting. Finally, third categorization key (10 questions) allowed the author to evaluate candidates Twitter accounts. Every category also covered multimedia content in the candidates' entries on every medium.

Research period was set to one month before election date (from 16 October to 16 November 2014), which is the peak time of political campaigning in Poland.

\subsection{Sampling}

This research is interested in investigating the ways of usage of candidates own Internet tools during electoral campaign to Lower Silesia Voivodeship Regional Assembly (Sejmik). Selected tools are: websites, official Facebook profiles and official Twitter accounts. Private 
Facebook accounts were not taken into account for the reason: while making preliminary research, focused on verification of existence of such tools, they were often hard to identify. Author had to make assumptions basing on the actions that could be perceived as stalking: profile photo, shared content or even liked pages to verify, if the account belongs to the candidate. Because of that, the number of private Facebook accounts in Table 1 is for an informative purpose only.

The data that enabled the author to justify making a research of online political communication in the region is a relevant number of inhabitants with access to the world wide web. According to the report published by Polish Central Statistical Office (2014) in October, households in Lower Silesia region that had computers was 78,2 per cent with the average for Poland of 77,1. When it comes to the Internet penetration, the result was also above the average (71,1 per cent) and it amounted to 71,9 per cent.

Social media market in Poland is growing each year. The report titled "Polish Internet Research" is published periodically by Megapanel/PBI and it provides actual data from Polish Internet landscape. The most corresponding report for this research comes was published in January 2015, and it covers the month, when the study was conducted (November). The data shows, that Facebook has sustained its hegemony on social media market share with almost 17 million users (Table 1) and nearly $80 \%$ of Internet penetration rate. Next two places in the table belongs to Google+ service and Polish equivalent of American social network service Classmates.com-nk.pl. The reason behind not making a research on these platforms is that high result of Google+ is the effect of high usage of Gmail service in Poland. In addition to nk.pl-constant downtrend since 2010 of this medium connected with huge "migration" to Facebook allows the author to bypass this service, because most likely it's occupied with non-active accounts and it is not a common platform for politicians to communicate with potential voters. Twitter in Poland is considered as an "elite" medium for politicians and journalists. In presented data it has reached the popularity of 2.5 million Polish internet users and penetration rate of almost $12 \%$ (Table 1 ).
Research sample for this study covered $100 \%$ of all the candidates. All of the $499^{1}$ names registered by the National Electoral Commission from all 11 election committees from the constituency of Lower Silesia have been taken into account. Table 2 is presenting the overall share of Internet tools during the campaign. After first step of conducting the research, there were 172 identified, official Internet communication tools. The most popular form of online communication among candidates to Regional Assembly was an official Facebook profile. There were 78 identified profiles among 499 candidates, which is 15,6 per cent of overall share. As may be observed in the Table 2, Twitter was second most used tool (9,6 per cent). Websites were slightly less popular with 46 (9,2 per cent). The visible difference of popularity between social media and the websites is explainable by the costs of projecting and establishing a website, which in a comparison to free of charge social media can be a barricade for parties with small financial resources. As mentioned before, substantial number of candidates had private Facebook account.

When it comes to the party-level analysis, the most active election committee on that area was the representatives of ruling party in Poland-Civic Platform (Platforma Obywatelska)-, who amassed a total of 54 identified tools. Other online active parties also had their representatives in Polish parliament: Left Democratic Alliance (Sojusz Lewicy Demokratycznej) with 24 identified tools, Law and Justice with total sum of 23 (Prawo I Sprawiedliwość) and Polish People's Party (Polskie Stronnictwo Ludowe) with 21. What is interesting, smaller parties such as New Right (Nowa Prawica) or National Movement (Ruch Narodowy) that often complained about marginalization by mainstream media, did not use opportunity to compensate this lack of presence through the Internet. The only exception was election committee of Non-partial Councilmen (Bezpartyjni Samorządowcy), who amassed 23 identified communication tools.

\footnotetext{
1 Until the 8 November 2015, the number was equal to 500 , but because of tragic accident one of the candidates passed away (Gadawa \& Wójcik, 2014).
}

Table 1. Social media market in Poland.

\begin{tabular}{lll}
\hline Social media platform & Users (numbers) & Internauts penetration (per cent) \\
\hline Facebook & $16,850,428$ & $78,57 \%$ \\
Google+ & $8,754,459$ & $40,82 \%$ \\
nk.pl & $4,899,343$ & $22,84 \%$ \\
Twitter & $2,528,881$ & $11,79 \%$ \\
Goldenline & $1,972,297$ & $9,2 \%$ \\
\hline
\end{tabular}

Source: Own elaboration based on data from Megapanel/PBI research from November 2014. 
Table 2. Overall share of Internet tools.

\begin{tabular}{|c|c|c|c|c|c|}
\hline Party name & Candidates & Website & Official Fb & Official TT & Private $\mathbf{F b}$ \\
\hline Polskie Stronnictwo Ludowe & 72 & 7 & 8 & 6 & 35 \\
\hline Demokracja Bezpośrednia & 5 & 0 & 0 & 0 & 1 \\
\hline Prawo i Sprawiedliwość & 71 & 8 & 12 & 3 & 30 \\
\hline Platforma Obywatelska & 72 & 19 & 20 & 16 & 45 \\
\hline Ruch Narodowy & 33 & 0 & 9 & 1 & 11 \\
\hline Sojusz Lewicy Demokratycznej & 70 & 6 & 11 & 7 & 33 \\
\hline Nowa Prawica & 45 & 0 & 7 & 0 & 12 \\
\hline Narodowe Odrodzenie Polski & 25 & 0 & 1 & 1 & 8 \\
\hline Bezpartyjni Samorządowcy & 70 & 7 & 6 & 10 & 28 \\
\hline Twój Ruch & 31 & 0 & 4 & 4 & 12 \\
\hline $\begin{array}{l}\text { Nasza Gmina Lubawka-Kalwaria } \\
\text { Lubawska }\end{array}$ & 5 & 0 & 0 & 0 & 1 \\
\hline Total & 499 & 46 & 78 & 48 & 216 \\
\hline
\end{tabular}

Source: own elaboration.

\subsection{Research Questions}

After the identification of online communication tools and getting a broad picture of electoral campaigning on a regional level, it became possible to formulate three research questions, which will be analyzed in the following section of this article:

\section{RQ1: To what extend do candidates use new media during election campaign?}

The content of the Internet is constantly changing. Web pages have become more interactive, the quality and multimedia potential of uploaded content has become more significant and valuable. The natural element of online landscape, social media, are demanding from its users much more technological awareness and proficiency. Likes, shares, followers and retweets are natural indicators of successful campaign on social media. This question will help to evaluate if the candidates are able to adapt to new conditions of functioning online.

\section{RQ2: Did smaller parties use new media as a form of compensation for their low presence in offline media?}

Although during the process of identification of online communication channels there was a substantial difference between the number of tools amassed by election committees represented by parties with representatives in parliament, there are 42 identified media owned by candidates from smaller parties. What is more, during further analysis not all of the communication tools have been qualified for research due to inactivity, and the proportion of owned media between relevant parties and smaller ones will decrease. Answering on that question will help the author to verify, if the parties with smaller financial resources was able to mark their presence in the web.

\section{RQ3: Are the candidates using Internet tools to interact with possible voters?}

Web 2.0 revolution changed the rules of communication in the Internet, granting new possibilities for Internet users to interact. Feedback from potential voter could be very valuable for the candidate, especially during regional campaign, where both sides are connected through bonds of spatial identity. By interacting with users on Facebook, candidates could easily expand their network of connections. This question will also verify if the regional election campaign was popular among citizens.

\section{Results}

After identifying all the active online communication tools, the author has created dataset with all of the quantitative results, which allowed for statistical calculations. All the data shall be broadly described and analyzed from qualitative perspective in this section. The analysis shall be conducted both from communication channel and party level.

\subsection{Websites}

The identification process allowed the author to gather 46 web pages which were analyzed using a dedicated categorization key. This section shall broadly describe the features and interaction potential of candidates' websites. Back in the era of web 1.0, pages in the Internet seemed to be static and their visual side did not draw user's attention. Nowadays, this tool can be a powerful way of informing, advertising and establishing the contact with potential voters.

In analyzing the research material, it was possible to distinguish pages with an informational function only (bulletin-board like pages) and websites with possibility of posting new entries. 19 analyzed pages (41\%) 
seemed to be only the Internet visiting cards, while 27 of them enabled candidates to share with their potential electorate the news about their campaign. The average number of posts in the period of last month before the elections was 3,8 with total 163 (Table 3) posts for all the candidates. Only 23 per cent of analyzed pages allowed it's viewers to share entries and materials within a share option (mostly via social media like Facebook, Twitter, Wykop.pl and Google+). What's more, not even a single comment on the website was identified during the research. This may explain the rather high proportion of non-interactive pages, along with the tendency to move dialogue on social media. However, the candidates tried to draw user's attention with additional multimedia content. Most of posted entries (74 per cent) had at least one photograph, image, video or attached link. Newsletter, as a form of staying in touch with the candidate and her or his actions was visible only on two analyzed pages. An Internet discussion forum wasn't identified on any of the analyzed pages.

Non-existent dialogue on the candidates' websites and much higher percentage of social media in identified online tools indicates this channel of communication as dominant in this campaign. This issue also affected the websites, where user could find all the links and embedded plug-ins for profiles of candidates in major social media services. 28 per cent of analyzed web pages had Facebook plug-in with current information posted on profile, but more than half (Table 3 ) of the research sample had a direct connection with most popular social media service with the link. Twitter was the second most popular social media linked to the pages, with 14 identified links (30 per cent). Other social platforms used by candidates and noticed on the websites were present in eight cases. Youtube.com was linked five times, while least popular services like Instagram or Flicker just once. Based on a research sample of analyzed material, websites owned by candidates re- flects the social media market share in Poland.

If the dialogue on the candidates' websites does not exist, the most important feature of this channel during electoral campaign ought to be the information. A typical Internet user and conscious voter should be able to easily find basic data about the candidate on the website. Being a representative in Regional Assembly is strongly connected with actions that should be taken in the specified area. Thus, the programme is the most desirable type of content on candidates' website, but only 59 per cent (27) of analyzed pages had information about planned activities. During every election, the personal aspect of the campaign is important. It's important for the conscious voter to gather the information about the candidate and his life. Personal information was identified on 91 per cent (41) of websites. This kind of data was usually presented in the section dedicated to the candidate him or herself ("About me"). Majority of candidates (87 per cent) provided the information on history of education and even more (91 per cent) about past activities, often connected to the political activity in the region.

The opportunity to contact the candidate via website was identified in 21 cases (46 per cent), where an online contact form appeared. However, the e-mail address was the most popular (60 per cent) method of communication. The least popular ways of communication assumed more direct contact. Phone number and direct address for correspondence was present respectively five and eight times.

When it comes to the party-level analysis, it's significant that the election committees with their representatives in parliament and local authorities made the 85 per cent of the research sample. The only exception was the Non-partial Councilmen committee with seven websites. Civic Platform, currently the ruling party in Poland was most visible in that area with 19 identified web pages (Table 3).

Table 3. The structure and features of websites.

\begin{tabular}{|c|c|c|c|c|c|}
\hline Election Committee & $\begin{array}{l}\text { Link to } \\
\text { Facebook } \\
\text { (in per cent) }\end{array}$ & $\begin{array}{l}\text { Share } \\
\text { option } \\
\text { (in per cent) }\end{array}$ & $\begin{array}{l}\text { Number of } \\
\text { entries (one } \\
\text { month) }\end{array}$ & $\begin{array}{l}\text { Number of } \\
\text { comments } \\
\text { (one month) }\end{array}$ & $\begin{array}{l}\text { Number of entries } \\
\text { with multimedia } \\
\text { content }\end{array}$ \\
\hline Polskie Stronnictwo Ludowe $(n=7)$ & 71 & 57 & 37 & 0 & 33 \\
\hline Demokracja Bezpośrednia $(n=0)$ & na. & na. & na. & na. & na. \\
\hline Prawo i Sprawiedliwość ( $n=8)$ & 25 & 0 & 35 & 0 & 14 \\
\hline Platforma Obywatelska $(n=19)$ & 66 & 22 & 40 & 0 & 26 \\
\hline Ruch Narodowy $(n=0)$ & na. & na. & na. & na. & na. \\
\hline Sojusz Lewicy Demokratycznej $(n=6)$ & 66 & 16 & 44 & 0 & 42 \\
\hline Nowa Prawica $(n=0)$ & na. & na. & na. & na. & na. \\
\hline Narodowe Odrodzenie Polski $(n=0)$ & na. & na. & na. & na. & na. \\
\hline Bezpartyjni Samorządowcy $(n=7)$ & 29 & 29 & 7 & 0 & 6 \\
\hline Twój Ruch (n=0) & na. & na. & na. & na. & na. \\
\hline $\begin{array}{l}\text { Nasza Gmina Lubawka-Kalwaria } \\
\text { Lubawska }(n=0)\end{array}$ & na. & na. & na. & na. & na. \\
\hline Total $(n=46)$ & 53 & 23 & 163 & 0 & 121 \\
\hline
\end{tabular}

Source: own elaboration. 


\subsection{Facebook}

The most popular social media service in Poland, Facebook gathered the most candidates during electoral campaign to Lower Silesia Regional Assembly with 78 identified, official fan pages. However, due to lack of activity (not even a single post during research period), the obvious expiration of a page (dedicated to the previous election campaign) or the death of a candidate, fan page research sample shrunk to 73 .

While building relations with potential voters on social media, candidates should avoid creating the impression, that their presence there is led strictly by the need of influencing voters. That dependence, which is common knowledge within the marketing discipline, has influenced political communication scholars, who are often describing voters as customers (e. g. Newman, 1999). However, during analyzed campaign 73 per cent (53) of the accounts has been created or activated just for election campaign period (Table 4). This attitude when exposed by the candidates shows, that in majority they have ignored the long-term relation building process. This should affect the basic indicator of popularity on Facebook which is the number of likes on a fan page. The total number of all the likes gathered on Facebook is 73819 (Table 4) with the average of 1011 per page. However, aside with popular politics with likes above the average, one candidate was a research sample stand-off. Robert Winnicki, a young activist from a National Movement is one of the most popular extreme right politicians, which explains his gathering of almost 31 thousand likes by himself. Because of that, author propose, that measure of popularity in that case should be expressed in median, which is 204 likes per fan page.

Another indicator of successful campaign on social media is the use of sharing potential, which is number of Facebook users speaking about the page. This statistic is telling us how many times the users of Facebook mentioned the fan page on their own timeline. If we think of that feature as a possibility to reach multiplied number of users, it is clearly very valuable for the candidate running for the mandate. The total number of users speaking about the candidates fan pages is 21755 (Table 4) with the average of 298. However, in that case the sample stand-off from the National Movement gathered more than a half of the total result, and 11300 users was mentioning his fan page in their posts. The median of this value was much lower than the average, and it was calculated to 50 users per candidate.

The activity of candidates on Facebook (number of entries in research period) was counted at 1444 entries (Table 4.) with an average of 19,8 . The median in that case was not far from the average -16 entries. Out of all identified entries, 973 posts contained multimedia content (773 posts consisted of pictures and 202 of videos) and 293 was the link to another Internet page.
This means, that 1266 posts (88 per cent) had an additional value and only 178 entries posted during election campaign was just plain text. Therefore, social media became the platform of multimedia sharing.

Facebook users can provide valuable feedback. Features like commenting and sharing can also reveal the success or the weakness of the campaign. However, the simplest way of measuring users' activity on candidate fan pages is the number of comments. There were almost three thousand identified comments during the last month of electoral campaign (Table 4). That number is more than twice that of candidates posts, but if we compare the median of Facebook posts (16) with the median of comments (9), that rather optimistic picture changes. One of the categories in the codebook was related to the non-commented posts. The result is verifying previous assumption, because 925 posts (64 per cent) were not commented at all. Another indicator of users' engagement in the campaign could be the presence of direct questions to the candidate with using the feature of "posts to the page". Only 11 candidates received personally addressed questions, which is only 14 per cent of research sample. All this data leads to the conclusion, that the campaign on Facebook was much more intensive than on websites. However, due to the high percentage of noncommented posts and the statistical distortion caused by stand-off candidate from National Movement, the campaign on dominant social service in Poland seems to reach a very sparse audience.

The party-level analysis of Facebook activity is similar to the activity in the world wide web, with a few exceptions. This time, smaller parties seemed to mark their presence during the online campaign. 23 identified fan pages was owned by the candidates from election committees without their representatives in Polish parliament. The ruling party (Civic Platform) candidates, owned the most of the pages (Table 4).

\subsection{Twitter}

The research sample for Twitter analysis is 24 Twitter accounts owned by the candidates. The same amount of accounts identified during the initial research turned out to be not active, which means that a single tweet was not identified one month before election date.

The specificity of Twitter analysis implies less complexity than the analysis of websites or Facebook fan pages. Thus, the codebook for Twitter consisted of 10 questions, which will help the author to describe the campaign performed on that service. While observing the attitude of the candidates during campaign period, the same category used for Facebook analysis was applied to this section of research as well. According to gathered data, 11 out of 24 Twitter accounts was created or activated one month before election (Table 5). The basic indicator of popularity for microbloggers is 
Table 4. Lower Silesia Regional Assembly candidates on Facebook.

\begin{tabular}{|c|c|c|c|c|c|c|c|}
\hline Election Committee & $\begin{array}{l}\text { Is the account } \\
\text { created/ } \\
\text { activated after } \\
1.10 .2014 \text { ? } \\
\text { (per cent of } \\
\text { accounts) }\end{array}$ & $\begin{array}{l}\text { Number } \\
\text { of likes }\end{array}$ & $\begin{array}{l}\text { Number of } \\
\text { users } \\
\text { speaking } \\
\text { about the } \\
\text { page }\end{array}$ & $\begin{array}{l}\text { Numbers } \\
\text { of entries } \\
\text { (one } \\
\text { month) }\end{array}$ & $\begin{array}{l}\text { Number } \\
\text { of entries } \\
\text { with } \\
\text { multimedia }\end{array}$ & $\begin{array}{l}\text { Number } \\
\text { of } \\
\text { comments }\end{array}$ & $\begin{array}{l}\text { Direct } \\
\text { questions to } \\
\text { candidate } \\
\text { (per cent of } \\
\text { candidates) }\end{array}$ \\
\hline Polskie Stronnictwo Ludowe $(n=5)$ & 60 & 1109 & 317 & 58 & 37 & 23 & 0 \\
\hline Demokracja Bezpośrednia $(n=0)$ & $\mathrm{N} / \mathrm{a}$ & $\mathrm{N} / \mathrm{a}$ & $\mathrm{N} / \mathrm{a}$ & $\mathrm{N} / \mathrm{a}$ & $\mathrm{N} / \mathrm{a}$ & $\mathrm{N} / \mathrm{a}$ & $\mathrm{N} / \mathrm{a}$ \\
\hline Prawo i Sprawiedliwość ( $n=12$ ) & 75 & 2703 & 719 & 230 & 155 & 249 & 0 \\
\hline Platforma Obywatelska $(n=19)$ & 65 & 11043 & 2759 & 403 & 302 & 817 & 20 \\
\hline Ruch Narodowy $(n=9)$ & 56 & 41007 & 13483 & 142 & 99 & 314 & 11 \\
\hline Sojusz Lewicy Demokratycznej $(n=11)$ & 91 & 2783 & 786 & 240 & 167 & 148 & 27 \\
\hline Nowa Prawica $(n=7)$ & 71 & 6340 & 709 & 125 & 84 & 403 & 14 \\
\hline Narodowe Odrodzenie Polski $(n=1)$ & 100 & 122 & 10 & 8 & 8 & 0 & 0 \\
\hline Bezpartyjni Samorządowcy $(n=6)$ & 6 & 6612 & 2880 & 206 & 102 & 959 & 33 \\
\hline Twój Ruch (n=3) & 33 & 2100 & 92 & 32 & 19 & 38 & 0 \\
\hline $\begin{array}{l}\text { Nasza Gmina Lubawka-Kalwaria } \\
\text { Lubawska }(n=0)\end{array}$ & $\mathrm{N} / \mathrm{a}$ & N/a & $\mathrm{N} / \mathrm{a}$ & $\mathrm{N} / \mathrm{a}$ & $\mathrm{N} / \mathrm{a}$ & $\mathrm{N} / \mathrm{a}$ & $\mathrm{N} / \mathrm{a}$ \\
\hline Total $(n=73)$ & 68 & 73819 & 21755 & 1444 & 973 & 2981 & 14 \\
\hline
\end{tabular}

Source: own elaboration.

Table 5. Lower Silesia Regional Assembly candidates on Twitter.

\begin{tabular}{|c|c|c|c|c|c|c|}
\hline Election Committee & $\begin{array}{l}\text { Is the account } \\
\text { created/ } \\
\text { activated after } \\
1.10 .2014 \text { ? } \\
\text { (per cent of } \\
\text { accounts) }\end{array}$ & $\begin{array}{l}\text { Number of } \\
\text { followers }\end{array}$ & $\begin{array}{l}\text { Number of } \\
\text { observed } \\
\text { users }\end{array}$ & $\begin{array}{l}\text { Total number } \\
\text { of tweets }\end{array}$ & $\begin{array}{l}\text { Hashtag } \\
\text { (per cent of } \\
\text { candidates } \\
\text { using } \\
\text { function) }\end{array}$ & $\begin{array}{l}\text { Retweet } \\
\text { (per cent of } \\
\text { candidates } \\
\text { using retweet } \\
\text { feature) }\end{array}$ \\
\hline Polskie Stronnictwo Ludowe $(n=4)$ & 50 & 961 & 1158 & 1367 & 50 & 50 \\
\hline Demokracja Bezpośrednia $(n=0)$ & $\mathrm{N} / \mathrm{a}$ & $\mathrm{N} / \mathrm{a}$ & $\mathrm{N} / \mathrm{a}$ & $\mathrm{N} / \mathrm{a}$ & $\mathrm{N} / \mathrm{a}$ & $\mathrm{N} / \mathrm{a}$ \\
\hline Prawo i Sprawiedliwość ( $n=2$ ) & 50 & 72 & 108 & 91 & 0 & 100 \\
\hline Platforma Obywatelska $(n=10)$ & 30 & 4267 & 1846 & 2200 & 60 & 90 \\
\hline Ruch Narodowy $(n=1)$ & 0 & 4570 & 93 & 752 & 100 & 100 \\
\hline Sojusz Lewicy Demokratycznej $(n=3)$ & 100 & 57 & 67 & 200 & 67 & 0 \\
\hline Nowa Prawica $(n=0)$ & $\mathrm{N} / \mathrm{a}$ & $\mathrm{N} / \mathrm{a}$ & $\mathrm{N} / \mathrm{a}$ & $\mathrm{N} / \mathrm{a}$ & $\mathrm{N} / \mathrm{a}$ & $\mathrm{N} / \mathrm{a}$ \\
\hline Narodowe Odrodzenie Polski $(n=0)$ & $\mathrm{N} / \mathrm{a}$ & $\mathrm{N} / \mathrm{a}$ & $\mathrm{N} / \mathrm{a}$ & $\mathrm{N} / \mathrm{a}$ & $\mathrm{N} / \mathrm{a}$ & $\mathrm{N} / \mathrm{a}$ \\
\hline Bezpartyjni Samorządowcy $(n=2)$ & 50 & 199 & 368 & 1125 & 100 & 100 \\
\hline Twój Ruch $(n=2)$ & 50 & 1374 & 429 & 780 & 100 & 100 \\
\hline $\begin{array}{l}\text { Nasza Gmina Lubawka-Kalwaria } \\
\text { Lubawska }(n=0)\end{array}$ & $\mathrm{N} / \mathrm{a}$ & $\mathrm{N} / \mathrm{a}$ & $\mathrm{N} / \mathrm{a}$ & $\mathrm{N} / \mathrm{a}$ & $\mathrm{N} / \mathrm{a}$ & $\mathrm{N} / \mathrm{a}$ \\
\hline Total $(n=24)$ & 46 & 11500 & 4069 & 6535 & 63 & 75 \\
\hline
\end{tabular}

Source: own elaboration.

the number of followers. That value for the research sample is 11500 with the average of 480 followers per candidate. However, three candidates amassed almost nine thousand following users, which makes the average misrepresented. The median of followers is more accurate for this case and it is calculated for 110 users. When we take into account the statistic of users followed by the candidates, the total amount in this case is 4069. The total amount and the average won't provide the broad picture again, so it was necessary to calculate median, which is 133 users followed. When we compare these two values it turns out, that candidates followed more often than they were followed.

A small percentage of microblogging candidates and the reverse following tendency may indicate, that Twitter as a tool of electoral communication can be harder to comprehend for the than other channels provided by new media. Using hash-tags (symbol \# before the tag) while posting new entry helps the Twitter community to navigate in the thousands of tweets and makes the information easier to find. Retweet means, that the user has posted someone else's entry on his account. The features of retweeting and hashtagging could describe user's advancement in using Twitter. Usage of retweet was noticed in 75 per cent of observations and hashtagging in 63 per cent (Table 5). That allows us to conclude, that the majority of tweeting candidates felt comfortable with this tool, and rather low interest rate in Twitter lies somewhere else.

When we take into consideration affiliation of the candidates, the Civic Platform turned out to be most active in that field again. Smaller parties, like National 
Movement or Non-partial Councilmen had only 13 per cent of observed accounts, which again can't allow answering positively on the RQ2.

\section{Conclusions}

By using content analysis, the author took an aim to investigate the way of using the Internet and social media by the candidates to Lower Silesian Regional Assembly during 2014 local elections in Poland. Almost $72 \%$ of Polish households have got access to the World Wide Web. While the Internet revolution has become the routine for most of the citizens, it is often the first place to look for the information about a political candidate. A website can be the basic tool in electoral communication for that matter. Analyzing the websites, the author has focused on the interactivity of the website, the availability of contacting the candidate via website and linking the site with social media profiles. The quality and frequency of updating the site was also analyzed, as well with the availability of basic information on the candidate. The candidate, who is estimating the potential of Internet communication tools should be aware of the fact, that many of potential voters are using Facebook and Twitter for browsing political information as well. After analyzing online political campaign from the regional perspective, it became possible to answer previously constructed research questions.

RQ1 was related to the broad landscape of electoral campaign online. The presumption of this research was that social media would be used as a free-of-charge alternative to websites after a very expensive campaign to the European Parliament. The overall share of Internet communication tools indicates that Facebook and Twitter were indeed twice as popular during the campaign. However, if we take into consideration the percentage of candidates who owned a website, it doesn't even make $10 \%$ of the observed population. The significant amount of websites had a form of static visiting card, without a possibility of posting, commenting or sharing content. Regardless of the fact, that most of identified entries on websites had a different kind of multimedia content, they did not meet with a single response from the viewers in a form of comment or any other feedback. All those data may indicate that the weight of the campaign has moved onto the social media. Thanks to the content analysis, it became possible to verify the candidates who are creating their online identity for the long time before the elections and those, who have launched their profiles only for the election campaign period. The Facebook campaign was treated as a "last minute" project. The majority of the candidates either created or activated their account during the last month of the campaign. Along with median of posting one entry per two days it resulted in a rather humble amount of likes and "talking about" indicators.

The second research question was about the elec- tion committees representing smaller parties-did they use social media as a form of compensation for the presence in the mainstream media? It is understood, that the lack of presence in the World Wide Web is connected with smaller budgets. However the election committee of Non-partial Councilmen has given the laudable example with being present online with seven websites, social media revolution has granted everyone the opportunity of being noticed, even without substantial financial resources. Smaller parties owned almost one-third of all identified Facebook fan pages, but their high results of amassed likes and "speaking about the page" indicator was not the result of a wellplanned and persistent electoral campaign. Research sample stand-offs, who has gathered the number of likes comparable with the national celebrities made the simple average a distorted value. It's also important that Twitter turned out to be terra incognita for the representatives of smaller election committees.

RQ3 concerned one of the most important issues connected with the new media, which is the ability to establish an almost instant contact with the candidate. The Regional Election campaign, where constituency is much smaller than in national elections is the time, when potential voters could find the opportunity to contact the candidate very valuable. However, the dialogue on the websites simply doesn't exist. Not a single comment was posted by the Internet users during the election campaign on the websites owned by candidates. Taking into consideration social media, Facebook was the place of dialogue, but the median of posts was much higher than the median of comments. Majority (64 per cent) of all entries posted on Facebook was not commented at all. The opportunity of asking direct questions to the candidate has been only used in 14 per cent of all observations. If we add to that account the situation on Twitter, where the median of the followers gathered by candidates is lower than the median of users that are followed, it is certain, that the online campaign did not draw attention of Internet users and potential voters.

Presented data allows the author to locate political campaigning in the regional level in Poland in the early post-modern era. The lack of interactive websites, amateur-like (in most cases) usage of social media and almost non-existing dialogue online allows to conclude the electoral campaign with the statement that the ineffective actions performed by the candidates in the Internet has met with an adequate response from the its users. Therefore, the author supports previously mentioned assumptions on political campaigns evolution.

\section{Acknowledgments}

Author would like to thank prof. Gregory Simons from Uppsala University for insightful comments and linguistic support. 


\section{Conflict of Interests}

The author declares no conflict of interests.

\section{References}

Alberski, R., Cichosz, M., \& Kobielska, K. (Eds.) (2013). Gra o regiony. Wybory do sejmików województw w $2010 r$. [The game of the regions. The Voivodeship Sejmik's electoral campaign in 2010]. Wrocław: Wydawnictwo Uniwersytetu Wrocławskiego

Baranowski, P., \& Jacuński, M. (2015). Development of online political communication in Poland in the context of the 2014 European Parliament election: technological innovation versus old habits. Central European Journal of Communication. Wroclaw: Wydawnictwo Uniwersytetu Wrocławskiego.

Borek, M., \& Jacuński, M. (2014). Parlamentarzysta online: Badanie aktywności polityków w internecie w perspektywie regionalnej [MP online: The analysis of politician's activity in the Internet from the regional perspective]. Wrocławskie Studia Politologiczne. Wroclaw: Wydawnictwo Uniwersytetu Wrocławskiego.

Budżet województwa dolnośląskiego niższy o $500 \mathrm{mln}$ zł niż w ubiegłym roku [Budget of Lower Silesia region lower by 500 million Polish Zloty than last year]. (2015). Retrieved from http://www.samorzad.lex.pl/ czytaj/-/artykul/budzet-wojewodztwa-dolnoslaskieg o-nizszy-o-500-mln-zl-niz-w-ubieglym-roku

Bukowski, M., Flis, J., Hess, A., \& Szymańska, A. (2011). Opcja czy osoba. Upartyjnienie versus personalizacja $w$ wyborach samorzqdowych [Option or person. Party versus personalization in regional elections]. Kraków: WUJ.

Canel, M. J. (1999). Comunicacion politica. Madrid: Tecnos.

Dobek-Ostrowska, B. (2007). Komunikowanie polityczne $i$ publiczne [Public and political communication]. Wrocław: Polskie Wydawnictwo Naukowe.

Gadawa, M., \& Wójcik, J. (2014, November 7). Tragedia pod Kłodzkiem. Kandydatka PiS-u zginęła w wypadku, walczyła o bezpieczną drogę [Tragedy near Kłodzko. Law and Justice candidate died in traffic accident]. Gazeta Wrocławska. Retrieved from http://www.gazetawroclawska.pl/artykul/3638098,t ragedia-pod-klodzkiem-kandydatka-pisu-zginela-wwypadku-walczyla-o-bezpieczna-droge,id,t.html

Garlicki, J. (2010). Komunikowanie polityczne-Od kampanii wyborczych do kampanii permanentne [Political communication-From electoral to permament campaign]. Warsaw: Elipsa Publishing House.

Gerstle, J. (1992). La communication politique. Paris: PUF.

Główny Urząd Statystyczny [Central Statistical Office]. (2014). Wykorzystanie technologii informacyjno(tele)komunikacyjnych w przedsiębiorstwach i gospodarstwach domowych w 2014 r. [The usage of information technologies in business and households in 2014]. Retrieved from http://stat.gov.pl/obszarytematyczne/nauka-i-technika-spoleczenstwo-inform acyjne/spoleczenstwo-informacyjne/wykorzystanietechnologii-informacyjno-telekomunikacyjnych-wprzedsiebiorstwach-i-gospodarstwach-domowych-w2014-r-,3,12.html

Harvey, K. (Ed.). (2014). Encyclopedia of social media and politics (Vols. 1-3). Thousand Oaks, CA: SAGE Publications. doi:10.4135/9781452244723

Megapanel/PBI Gemius. (2014). Polish Internet research analysis. Retrieved from http://www.pbi.org.pl/pl/ aktualnosci/231/polski-internet-w-listopadzie-2014

Newman, B. (1999). Handbook of political marketing. Thousand Oaks, CA: SAGE Publications.

Norris, P. (1997). Electoral change since 1945. Oxford: Wiley-Blackwell.

Perloff, R. M. (1998). Political communication: Politics, press and public in America. Manwah, New Jersey: Lawrence Erlbaum Associates.

Plit, A. (2008). Komunikowanie polityczne w czasie trwania kampanii wyborczej oraz w okresie między wyborami [Political communication during electoral campaign and between elections]. Warsaw.

\section{About the Author}

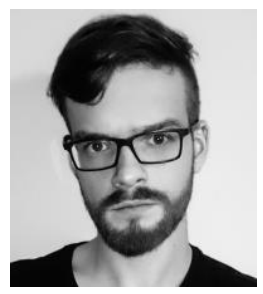

Paweł Baranowski

Paweł Baranowski is a Ph.D. candidate at the Institute of Political Science at Wroclaw University. He is the editor of the book reviews section in the Central European Journal of Communication and former Secretary of the Polish Communication Association. He has taken part in many international research projects. His scientific interests are focused around political communication, social media and journalism studies. 
Annex. List of the election committees from the Lower Silesia Voivodeship during the 2014 Regional Assembly Elections.

Polskie Stronnictwo Ludowe-Polish People's Party

Demokracja Bezpośrednia-Direct Democracy

Prawo i Sprawiedliwość-Law and Justice

Platforma Obywatelska-Civic Platform

Ruch Narodowy-National Movement

Sojusz Lewicy Demokratycznej-Democratic Left Alliance

Nowa Prawica-New Right

Narodowe Odrodzenie Polski-National Polish Revival

Bezpartyjni Samorządowcy-Non-partial Councilmen

Twój Ruch-Your Movement

Nasza Gmina Lubawka-Kalwaria Lubawska-Our Commune Lubawka-Kalwaria Lubawska 